\title{
SELF-CARE OF ELDERLY CANCER PATIENTS UNDERGOING OUTPATIENT TREATMENT ${ }^{1}$
}

\author{
Lucimara Sonaglio Rocha ${ }^{2}$, Margrid Beuter ${ }^{3}$,Eliane Tatsch Neves ${ }^{4}$, Marinês Tambara Leite ${ }^{5}$ Cecília Maria \\ Brondani ${ }^{6}$, Nara Marilene Oliveira Girardon Perlini ${ }^{7}$
}

${ }^{1}$ Article extracted from the dissertation Idosos convivendo com câncer: possibilidades para o cuidado de si, submitted to the Nursing Graduate Program of the Federal University of Santa Maria, 2011.

${ }^{2}$ Master in Nursing. R.N. at Hospital Beneficente Dr. Cesar Santos de Passo Fundo. Rio Grande do Sul, Brazil. Email: lucimarazz@ hotmail.com

${ }^{3}$ Ph.D. in Nursing. Associate Professor of Nursing at the Department of Nursing and Nursing Graduate Program of the Federal University of Santa Maria. Rio Grande do Sul, Brazil. Email: margridbeuter@gmail.com

${ }^{4}$ Ph.D. in Nursing. Assistant Professor of Nursing at the Department of Nursing and Nursing Graduate Program of the Federal University of Santa Maria. Rio Grande do Sul, Brazil. Email: elianeves03@gmail.com

${ }^{5}$ Ph.D. in Biomedical Gerontology. Adjunct Professor at the Federal University of Santa Maria, Palm Tree Campus Missions. Rio Grande do Sul, Brazil. Email: tambaraleite@yahoo.com.br

${ }^{6}$ Ph.D. student, New Frontiers Interinstitutional Doctoral Program. R.N. at the University Hospital of Santa Maria. Rio Grande do Sul, Brazil. Email: ceciliabrondani@hotmail.com

${ }^{7}$ Ph.D. in Nursing. Assistant Professor of Nursing at the Department of Nursing and Nursing Graduate Program of the Federal University of Santa Maria. Rio Grande do Sul, Brazil. Email: nara.girardon@gmail.com

\begin{abstract}
This is a qualitative descriptive study with the aim to analyze the self-care of elderly cancer patients undergoing outpatient treatment, from the perspective of their autonomy. Fifteen elderly individuals undergoing treatment in a blood-oncology outpatient center of a university hospital participated in the research. Data were collected with semi-structured interviews conducted in 2010. Independence and ability for self-care by the elderly patients were evaluated using the Katz and Lawton scales. The data collected were submitted to thematic analysis. Four categories were identified: manifestations of self-care of elderly cancer patients; care in the family and its dynamics; adaptation to the limitations of the disease; and living with finiteness. In conclusion, the autonomy for self-care of the elderly patients is manifested in the concern with diet, knowing their bodies' limits, the changes imposed by living with cancer and family support.
\end{abstract}

DESCRIPTORS: Nursing. Self-care. Neoplasms. Health of the elderly. Personal autonomy.

\section{O CUIDADO DE SI DE IDOSOS QUE CONVIVEM COM CÂNCER EM TRATAMENTO AMBULATORIAL}

RESUMO: Pesquisa qualitativa e descritiva, cujo objetivo foi analisar o cuidado de si de idosos que convivem com o câncer, em tratamento ambulatorial, na perspectiva de sua autonomia. Participaram da pesquisa 15 idosos que realizavam tratamento em um ambulatório de hemato-oncologia de um hospital universitário. Os dados foram coletados por meio de entrevista semiestruturada em 2010. A independência e a capacidade do idoso para o autocuidado foram avaliadas com o uso das escalas de Katz e Lawton. Os dados foram submetidos à análise temática. Foram identificadas quatro categorias: manifestações do cuidado de si de idosos que convivem com câncer; o cuidado em família e sua dinâmica; a adaptação às limitações da doença; e a convivência com a finitude. Conclui-se que a autonomia para o cuidado de si dos idosos manifesta-se na preocupação com a alimentação, no conhecimento dos limites do corpo, nas mudanças impostas pela convivência com o câncer e no apoio da família.

DESCRITORES: Enfermagem. Autocuidado. Neoplasias. Saúde do idoso. Autonomia pessoal.

\section{EL CUIDADO DE SÍ DE ANCIANOS QUE CONVIVEN CON CÁNCER EN TRATAMIENTO AMBULATORIO} RESUMEN: Investigación cualitativa y descriptiva cuyo objetivo fue analizar el autocuidado de ancianos que conviven con cáncer en
tratamiento ambulatorio en la perspectiva de su autonomía. Participaron de la investigación 15 ancianos que realizaban tratamiento en
un dispensario de hemato-oncología de un hospital universitario. Los datos fueron recolectados a través de entrevista semi-estructurada
en 2010. La independencia de las personas mayores y la capacidad para el autocuidado se evaluó a través de las escalas de Katz y
Lawton. Los datos fueron sometidos al análisis temático. Se identificaron cuatro categorías: manifestaciones del autocuidado de ancianos
que conviven con cáncer; el cuidado en familia y su dinámica; la adaptación a las limitaciones de la enfermedad; la convivencia con
la finitud. Se concluye que la autonomía para el autocuidado de los ancianos se manifiesta en: la preocupación con la alimentación, el
conocimiento de los límites del cuerpo, los cambios impuestos por la convivencia con el cáncer y apoyo familiar.

DESCRIPTORES: Enfermería. Autocuidado. Neoplasias. Salud del anciano. Autonomía personal. 


\section{INTRODUCTION}

As the population ages, in Brazil and throughout the world, problems resulting from aging, including the advancement of chronic diseases, are identified. By 2020, it is estimated that $80 \%$ of the disease burden in developing countries will be due to chronic health problems. ${ }^{1}$ Cancer is among the growing number of chronic diseases, which can affect anyone at any age, though its incidence increases after 60 years of age. ${ }^{2}$ In 2008, in the state of Rio Grande do Sul, this disease was considered the second leading cause of death in people aged 60 years and over, accounting for $22.1 \%$ of total deaths. ${ }^{3}$

Throughout history, cancer has been conceived of as a fatal disease. Even with technological and medical advances in surgery, pharmacology and radiation therapy for its treatment, cancer still presupposes the idea of death. Diagnosis of cancer brings with it awareness of the possibility of death for the patient. This experience is often accompanied by anxiety, hopelessness, isolation and fear, which pervade the course of treatment for patients and their families. ${ }^{4}$

Cancer is a frightening disease, just as old age is a stigmatized stage of life. Therefore, the care of elderly cancer patients is very complex. In this context, nursing plays an important role in the course of cancer treatment, in terms of monitoring the physical, psychological and social conditions of the elderly during the disease process. ${ }^{5}$

With regard to impacts caused by cancer treatment, outpatient therapy has been shown to be an excellent strategy to alleviate the suffering of patients, allowing for greater autonomy in comparison to hospitalization. Autonomy is understood as the capacity to act for oneself, to be able to choose and propose ideas, and act responsibly, and refers to the individual's right to self-government, making choices for oneself, and acting as the protagonist in their health-disease process. ${ }^{6-7}$

Exercising autonomy implies taking responsibility for one's own health. It is the right of cancer patients to be aware of their diagnosis, treatment and prognosis, so that they are able to decide how to conduct aspects of self-care in this stage of life. It is noteworthy that understanding the autonomy of elderly cancer patients is multifaceted and complex, since the disease process imposes constraints that hinder the exercise of this right. ${ }^{8}$
Furthermore, it is noteworthy that the elderly commonly have chronic health problems and disabilities, which are diagnosed late, and hinder preventive interventions or those that minimize their complications. Thus, it is important to maintain the functional capacity and autonomy of elderly people, and to implement actions for health promotion, and for the prevention and control of risk factors that can lead to the emergence of the condition of fragility in elderly patients. ${ }^{9}$

The vulnerability of the elderly in the social context can be reflected in their health. In contrast, the decision by the elderly to attain their health goals strengthens them, facilitating and encouraging reduced dependence on the professional-patient-family relationship. ${ }^{10}$ In this sense, it is important to search for strategies that help elderly patients become participatory and active in society, in order to ensure expression of their autonomy. This possibility is focused on the practice of the foundations of self-care.

Self-care values the subjectivity of the human being, and requires nursing to assist individuals in their health care, with the objective of improving their quality of life. The moment in which measures for self-care are used in nursing practice, an ethical behavior for life is adopted, awakening responsibility and concern for living. ${ }^{11}$

Thus, in view of the foregoing, the question is: how do elderly cancer patients in outpatient treatment care for their health? To answer this question, the aim of this study was to investigate the self-care of elderly cancer patients in outpatient treatment, from the perspective of their autonomy.

\section{METHODOLOGY}

This is an exploratory, descriptive study with a qualitative approach, developed with elderly patients diagnosed with cancer, undergoing outpatient hematology-oncology treatment at a university hospital in the Brazilian state of Rio Grande do Sul.

Data were collected by means of semi-structured interviews applied between February and April of 2010. The interviews were audio-recorded and transcribed, and conducted using two central themes: day-to-day health care performed and the life changes generated after diagnosis and treatment of cancer.

The Katz and Lawton scales ${ }^{12}$ were applied to verify the conditions of the elderly to care 
for themselves, with respect to their ability for self-care and to lead an independent life within their social environment. The Katz scale permits the evaluation of basic Activities of Daily Living (ADL), assigning different degrees of functional independence to subjects in the acts of: bathing, dressing, toileting, transferring, continence and feeding. The Brazilian version adopts the following classification: (0) independent in all functions; (1) dependent in one function and independent in five; (2) dependent in two functions and independent in four; (3) dependent in three functions and independent in three; (4) dependent in four functions and independent in two; (5) dependent in five functions and independent in one; (6) dependent in all functions. ${ }^{12}$

The Lawton scale enables examination of the functional performance for performing Instrumental Activities of Daily Living (IADL), which include ability to use the telephone, mode os transportation, shopping, food preparation, housekeeping, laundry, responsibility for own medications and ability to handle finances. This scale has seven domains, and each one has three items that receive one of the following scores: (1) dependent, (2) need for assistance and (3) independent. Its total score ranges from 7 to 21 , in which the lower the value obtained by the elderly patient, the greater their degree of impairment to lead an independent community life. ${ }^{12}$

Inclusion criteria for the study were: being elderly (60 or older), diagnosed with cancer, undergoing treatment for at least three months, having capacity for verbal communication and comprehension, and being aware of their cancer diagnosis. The treatment time criterion was established by adopting an initial time limit for the elderly patients to experience the diagnosis and their new life condition.

The selection of study subjects came from analysis of their medical records. The subjects who met the inclusion criteria were invited to participate in the study. Fifteen elderly cancer patients were interviewed. The determination of this number took into account the criterion of data saturation. ${ }^{13}$

Qualitative data were subjected to thematic analysis, specifically content analysis. ${ }^{14}$ Operationally, according to the reference used, the thematic analysis was developed in the following steps: pre-analysis, comprising the reading of all of the material, constitution of the corpus, and formulation of hypotheses and objectives; exploration of the material, with identification of the different ideas and meanings contained in each response provided by the subjects with the classification and aggregation of data; and treatment of the results obtained and their interpretation, with the description of the main meanings attributed by the elderly in their responses to questions on being elderly and experiencing cancer, through the constant lens of self-care. Simple descriptive statistics were used for handling data related to characterization of the study subjects.

The study followed the ethical principles of Resolution 196/96 of the National Health Council, ${ }^{15}$ approved by the Research Ethics Committee of the institution under the Certificate of Presentation for Ethical Appraisal n. 0317.0.243.000-09. All participating subjects signed a Free and Informed Consent Form, and were informed on the purpose and implications of their participation in the research, as well as guaranteed confidentiality and anonymity. The identity of the participants was maintained, recording their statements with the letter E (for elderly), followed by an Arabic numeral that did not correspond to the order of the interviews.

\section{RESULTS AND DISCUSSION}

A total of 15 elderly patients participated in the study, of which eight were women and seven were men. Their ages ranged from 61 to 84 years. Regarding education, two were illiterate, 12 had incomplete primary school education, and one had completed high school. Regarding marital status, ten were married, three were widowed and two divorced. One study on the epidemiology of cancer showed that the majority were female $(60.2 \%)$, had completed high school $(37.3 \%)$, were retired or pensioners $(39.8 \%)$, with income from one to three minimum wages $(67.4 \%)$, and were aged 55 years or older $(74.7 \%) .{ }^{16}$

In regard to income, all of the elderly patients were retired, with fixed incomes of between one to four minimum wages. Most of the participants were financially independent, as this is an essential factor for autonomy that positively influences quality of life, though two individuals declared to be unable to manage their own financial resources. All of the participants lived in their own residence.

Regarding localization of the cancer, six participants were undergoing treatment for 
breast cancer; five for prostate cancer; one for colon cancer; one for lung cancer; one for skin cancer and one for pancreatic cancer. Research showed that most incidents continue to be prostate cancer among men and breast cancer among women. ${ }^{16}$

Regarding the Katz scale assessment of the participants' functional capacity, ${ }^{12} 13$ were classified as independent for all basic activities of daily living. Two elderly patients (E:1 and E:6) were evaluated to be dependent for one activity, that being the item continence. This result was due to the physiological changes resulting from the cancer. One patient (E:1) had fecal incontinence due to surgical treatment of colon cancer, and one patient (E:6) had urinary incontinence due to surgical treatment of prostate cancer. Although not all chemotherapy drugs cause side effects, they do exist, with the most common being hematological, gastrointestinal, cardiac, hepatic, pulmonary and neurologic, among others. ${ }^{2}$

Regarding instrumental activities of daily living, as assessed by the Lawton scale, ${ }^{12}$ ten elderly patients were classified as independent, three needed help, and two were dependent. The patients who needed help (E:4, E:5 and E:7) were considered as such due to their need for help performing household activities, much more from the delegation of such activities to the family than by real inability to perform them. The two elderly patients considered dependent expressed inability to perform instrumental daily living activities as a result of clinical depression, one (E:9) as a result of divorce from their spouse, and the other (E:12) for non-acceptance of the disease, situations that led them to a condition of social isolation.

With regard to this condition, one study that sought to assess the functional capacity of the elderly in the community identified that $58.1 \%$ were dependent for one or more instrumental activities of daily living. This shows that most elderly people can care for themselves at home, but are unable to live independently in the external environment. ${ }^{17}$

Self-care is a natural and personal part of the daily life of each being, and the elderly study participants showed this practice in different ways. The following categories emerged from the thematic analysis: manifestations of self-care of elderly patients living with cancer; family care and its dynamics; adaptation to the limitations of the disease; and living with finitude.

\section{Manifestations of self-care of elderly patients living with cancer}

Regarding the manifestation of self-care of the elderly patients, the statements revealed that their conception of care is linked to eating practices: the care that I have at home is with food. Food is very important, like when we make potato or pasta, we take the rice out. I eat more salad - four or five types per day. Basically, I take care of myself through diet (E:2).

Living with cancer involves changes and adaptations to the diets of elderly patients, especially with how food is prepared: I can't cook more than two hours; I have to prepare and eat. I can't eat raw greens; I have to cook everything in the microwave. I have to take such care. Even juice and stuff, I cook everything there [microwave] (E:5).

The elderly participants in this study indicated that they incorporated concern with how food is prepared into their daily care. In this sense, it is a form of self-care that expresses a positive view of the individual about the issues with which he or she should be concerned, in order to achieve complete well-being. ${ }^{18}$

To take care of oneself it is essential to know oneself. In this sense, it is a return to oneself and refers to acts of knowledge, referring to the attention, look and perception. Thus, it is necessary to become and return to oneself, in order to know what is useful for self-care and what is not. ${ }^{18}$

Elderly cancer patients determine limits between what they should or should not do based on knowledge of themselves, their singularities, symptoms of the disease and their body's reaction to the treatment. I take care of myself, I don't go in the sun, I don't walk a lot, I don't exert myself. There is certain work that I can't do [...]. I do my little chores, very slowly. But I don't do things I can't do, that will hurt me (E:7).

The care that the elderly patients provide to themselves, to their bodies, is clear in the physical limitations resulting from the disease and the aging process. Nevertheless, these limitations keep them from their daily tasks, because work is a way of staying active and productive. I take care of myself at home. I do everything! If I need anything, the girls do it, but I never need anything. I even wash clothes alone, sometimes I wait for them to connect the washing machine for me to wash. The machine is located in a little place where I drink my maté, so I turn on the machine and it does it all by itself, while I am drinking my maté. Cleaning around the house, I always do it, the day I am angry I do a better cleaning (E:14). 
The aging associated with chronic illness is not synonymous with uselessness or dependency. The family plays a fundamental role in these circumstances, as it can strengthen the self-care of elderly cancer patients, in so far as it permits them to exercise their autonomy.

Although changes have occurred in the family model over the years, this has not significantly affected the form of care, because the family remains the primary form of informal support to the elderly. Nevertheless, in households that underwent changes in the family structure, to living only with a spouse and without children or other family members who can provide support, the possibilities for care are more restricted. ${ }^{19}$

Accordingly, it can be rewarding to the elderly to care for themselves, while continuing to care for the people with whom they live. I take care of myself and take care of my wife. She has always been very sick, since she was young. It was me who raised the children [...]. I make the food. I follow the directions the doctor gave me, I take care of myself well, and my wife, too (E:3).

The Family Health Strategy should propose actions that maintain and increase cognitive functions in elderly patients. Additionally, it should develop actions to promote social interaction and greater involvement of families of the elderly. This is because the limitations and adaptations for carrying out activities by the elderly may be a result of the aging process, or the development of chronic, degenerative diseases. ${ }^{17}$

Caring is a way of being human, part of its nature and constitution, and thereby obeys the human essence. Human beings do not exist without care; in order to survive, an individual must give or receive care. Thus, it is possible to affirm that care emerges when the existence of someone is meaningful to others, and this makes them care for that person. ${ }^{20}$ Taking care of oneself is more than providing conditions for the continuity of life. For the elderly patients in this study, it also permeates the responsibility of caring for others.

\section{Family care and its dynamics}

Historically, a division of labor is identified within the family, in which women assume the tasks of caring, and men are responsible for economic support. Currently, increasing changes to gender roles are being observed, resulting from entry of women into the labor market, thereby allowing for greater equality in performance of these roles. Nevertheless, women from different educational levels and generations, whether they work outside of the home or not, share the experience of unequal burden of domestic work. ${ }^{21}$

This division does not always happen in this way, as verified in the study: I have somebody to take care of the house today. I am no longer able to take care of it. [...] I don't do street services anymore; now my child does them. My husband never worked outside the home, he has had a sight impairment from birth, so he is my domestic worker. I have always worked outside the home, and then I would come home and everything was ready. Also, he never worked! Someone had to do the domestic work: we reversed the roles (E:2).

Habits in health care are considered characteristics associated with the feminine universe. Taking care of others, especially a family member in the home, has been constituted as a female task, complex and subject to intervening variables, including social attributions and those that are culturally constructed for genders, which are experienced as natural attributes, when in reality they are social constructs that are intended to regulate the relations of power between the genders. ${ }^{22}$ Nevertheless, in some cases, an inversion of the culturally defined roles was observed in families: the woman assuming financial support and the husband, care of the home.

Added to the division of labor among its members, the family emerged as an important source of support to elderly members living with cancer, whether through demonstration of concern and support, or the provision of direct care. Now I can take care of myself alone, but before, when I could not, my daughter, wife and even the kids helped me. Here in the hospital, I always had a companion, when it wasn't my wife, it was my daughter. The children, it's a marriage, family is so difficult. My family cares for me very much. Oh, a lot! Woe to me if I go to work! Woe to me if I go out in the sun (E:5).

The family is a system in which values, beliefs, knowledge and practices combine to form an explanatory model of health and disease, through which a dynamic develops of its own functioning, which promotes health, and prevents and treats illness among its members. From the family, a support network for the patient is built through extra- and interfamilial integration. ${ }^{23}$ The experience of a disease such as cancer can compromise the quality of life of the elderly patient in different ways, hence the importance of the family as a source of support and comfort: this is my daughter [daughter enters the room], she also did chemo, it 
ended this week, she is really elegant [happy]. I have my grandson, too, who is also doing chemo, he is nine years old, but he has courage, more than me, he gives me advice. He says, 'Grandma, you will be fine.' Everything that happens to him happens to me, too. When my hair fell out, he was really happy that I was like him, then it was not only him (E:9).

Most of the time, cancer treatment is long, invasive and aggressive, generates emotional and physical stress, and requires effort, confidence and patience from the patients and those around them. The family is the space in which they share and live with the predicament, and the impact of the disease. It is also the place where strength can be found to face the adversity, as well as encouragement to fight for life and overcome the illness, from the potentiation of actions that promote self-care from each member.

\section{Adaptation to the limitations of the disease}

Cancer remains among the diseases that most cause fear and worry in the population. Yet the disease has its own meaning for each person, depending on its manifestations, the presence of tumors, changes in body image, and the treatment to which the individual is subjected. These aspects make the elderly patient more susceptible to limitations and the need for adaptation imposed by the disease. It changed, because it took away my freedom...I can't eat what I want and like to eat, I can't go out, walk, because of the problem with the bag [colostomy]. Everything is like that...So I like to stay home. We end up being more isolated. I lost the freedom to go out, going out is bad, you have to change the bag, I always have to carry a bag in the [car] trunk (E:1).

Social isolation can be a consequence that the cancer imposes on the elderly patient. In general, isolation is noticeable due to the internalization of the process of loss: loss of physical image, of people who are close, of work and health, ${ }^{24}$ which often also includes the loss of autonomy.

Another point related to the adaptations imposed by cancer on the lives of elderly patients concerns their stopping daily activities, as well as the sense of guilt, because they consider themselves to be a burden on family members concerned about their health. It changed a lot because I was accustomed to going to the field to work. Now, staying at home is tiring. What can I do? This was the change. I see the children worried about me, because I was fine, but now they don't want me to die. Now we don't work, just stay there, I can't! So, I stay practi- cally alone. One always stays home, my daughter or wife, my sons go to the fields, hence it seems that the day does not pass (E:5).

Self-care is expressed by the need to conform and to try to adapt to a new condition of life, due to the limitations imposed by the disease, depriving themselves of the work activities developed, and living with the family group.

Among the difficulties faced by elderly patients, there is the need to live with the adverse effects from the antineoplastic treatment, to a greater or lesser intensity: I had already done the surgery [mastectomy], then when I started 'chemo' I felt nausea, I was vomiting, my bowels stopped, I lost my hair, then later I had diarrhea, everything after the chemo (E:9).

Adverse effects are considered one of the main limitations of treatment, and a condition of difficult adjustment. Nausea and vomiting were found to be the most common side effects among the respondents, causing them great physiological and emotional wear. Regarding surgical treatment, one elderly patient who underwent a prostatectomy gave the following account: even after the surgery, a little urine still leaked out, and I always have to have a liner. After I had the surgery, I could no longer have sex with my wife, but it's okay, what am I going to do? I'm getting well... (E:6).

Radical prostatectomy is one of the preferred methods of treatment for prostate cancer, due to its high cure rates. Nevertheless, it presents a high percentage of late complications, the most significant being urinary incontinence and sexual impotence..$^{24}$ It is important to note that satisfaction with sex life and control of body eliminations directly reflects on the (dis)satisfaction of the elderly patient with life in general and self-care, as the loss of one or both capabilities may cause devastating effects on quality of life.

Yet antineoplastic treatment can have beneficial effects, these outweigh the adverse effects of the drugs used, or else cause no change. Ever since I started doing the chemo, I no longer feel pain. I feel some nausea and fever, but it's only for one day, then it passes (E:4). Nothing changed, nothing, nothing, because I've always been a very healthy person, I didn't change anything. I didn't become swollen, I didn't get yellow, I took it all as a joke, I didn't take it seriously (E:10).

Pain is a perceptual, sensory and emotionally unpleasant experience, whose interpretation relates to cultural, emotional and sensory factors that can only be shared from the account of who 
feels it. ${ }^{25}$ Pain incapacitates the patient, causing organic, emotional, behavioral and social damage, hence the importance attached by the elderly in the study to having their pain relieved or cured with the treatment that they were undergoing. In this regard, it is noteworthy that the presence of pain may be a factor that limits autonomy and compromises self-care.

It is observed that adaptation or not to an event such as cancer treatment depends on numerous factors that are cultural and emotional, previous experiences and personal characteristics to face similar situations in a different manner. ${ }^{25}$ These characteristics, in turn, will also affect how elderly patients take care of themselves.

\section{Living with finiteness}

In the social imagination, aging is associated with the end of an era, synonymous with suffering, loneliness, illness and death. It is difficult to relate any pleasure of living with this phase of life. ${ }^{26}$ It is with this reflection that elderly people living with cancer face the aging process. Reactions to illness from cancer at an advanced age include both denial and resistance, and acceptance of the process.

Fear of death is associated with personal suffering, that is, the possibility of experiencing physical pain. ${ }^{27}$ The elderly participants expressed concern with finitude, relating it to the situation of aging and living with cancer. My daughter worries a lot about us. She wanted to take me there, but I have all the children who live around here. Oh, I am old, tomorrow or after I, you know...get old...you are subject... when you see, all of a sudden, you can go [...] Now I have this deviation [colostomy]. I'm already well-adapted. I spoke with this doctor from here [...] he wants to put a new one in, but I think I'll leave it at that. I am already old (E:1).

The process of aging and living with cancer lead the elderly to reflect on their finitude. Facing this context, the elderly patient does not seem inclined to change the dynamics of life, avoiding hazards such as exposure to a new procedure. These patients feel adapted to the demands of their new health condition/disease. Even living with the proximity of death, positive feelings are perceived towards this phase of life: [...] I was really afraid of old age, but I'm enjoying it. [...] We are respected, treated well, I don't know if it's because of age, or what (E:1).

The positive perception of this phase of life contrasts to other studies about aging, with other individuals talking about the elderly, focusing on aging as something negative, because, in general, the people involved are loaded with stereotypes that prevent the construction of positive elderly identity. ${ }^{28}$

When it comes specifically to cancer, a discourse can be identified based on figures of speech as a way of avoiding direct reference to the disease, due to the stigma surrounding it. Given its significance, it becomes difficult to even pronounce the name. Sometimes it makes me want to stop the 'chemo,' because I think that I have nothing more from my mood. I don't think I have a bad disease, my mood is good, for home, for work, for everything, I don't feel any pain (E:1).

In this sense, it is sought to continually encourage people to fight for survival, rather than simply waiting for death. This new perspective of the disease provides the patients with knowledge about their bodies and how to deal with subjective suffering. In addition, there is valuation/enhancement of monitoring and social and family support to patients and families, aimed at coping with stigmas and biases. ${ }^{29}$

Therefore, the very acceptance of the disease by elderly patients and their families is a challenge to be overcome. If I didn't have faith, my first cross would already have fallen. When the tests came back and it was confirmed, it was the doctor himself who said, 'hey, it's cancer.' At the time, I got weak... I said, God is greater than all, I have divine protection! And $\mathrm{He}$ really was (E:8).

Spirituality appeared as a strategy used by the elderly patient cited above to cope with the disease, strengthening his connection with God and calm acceptance of the situation. Thus, enduring the illness and treatment require strength and perseverance from the person who experiences cancer. Belief in the existence of a higher power assists and enhances beneficial energies for cure ${ }^{30}$ so that the elderly patient can implement actions in an autonomous manner, focused on self-care.

\section{FINAL CONSIDERATIONS}

Self-care is manifested differently for elderly cancer patients in outpatient treatment. One way is related to diet, which emerged as a nutritional need for healthy living, modified due to aspects related to the aging process and living with cancer.

Self-care of the elderly was also present through self-knowledge. On this matter, the elderly participants signaled that they were aware of 
the limits of their bodies, both in terms of reactions following antineoplastic therapy, and in maintaining work activities. The fact that they have the physical and psychological conditions to exercise self-care was a cause for satisfaction among the elderly participants, who are interested in extending this care to other members of their families.

From the participants' point of view, adapting to the aging process, as well as to the changes imposed by illness from cancer, was also a form of self-care. This is because living with aging and cancer can have different effects on an individual's life if he or she does not use coping strategies adequately. Adaptation, or not, depends on the cultural and emotional aspects experienced, previous experiences, and personal characteristics of each elderly patient.

In the division of tasks, in terms of emotional support to the elderly cancer patient, the family proved to be an important tool both for viability and unviability of self-care, depending on the position taken regarding the principles of autonomy and beneficence. Another factor that contributed to the self-care of the elderly in the face of the experience was the manifestation of spirituality, in the belief in a higher power, which comforts in times of trouble and distress.

Regarding the results of this study, it is believed that they may help to explore the issues related to the self-care of elderly patients, contributing to develop other important studies on this topic in nursing.

\section{REFERENCES}

1. Organização Mundial da Saúde.Cuidados inovadores para condições crônicas: componentes estruturais de ação. Relatório mundial. Brasília (DF): MS; 2003.

2. Instituto Nacional do Câncer. Estimativa 2008: incidência de câncer no Brasil. Rio de Janeiro (RJ): INCA; 2007.

3. Secretaria da Saúde (RS). Núcleo de Informações em Saúde. E52. Estatísticas de Saúde: mortalidade 2009. Porto Alegre (RS): Secretaria da Saúde; 2010.

4. Borges ADVS, Silva EF, Toniollo PB, Mazer SM, Valle ERM, Santos MA. Percepção da morte pelo paciente oncológico ao longo do desenvolvimento. Psicol Estud. 2006 Mai-Ago; 11(2):361-9.

5. Machado SM, Sawada NO. Avaliação da qualidade de vida de pacientes oncológicos em tratamento quimioterápico adjuvante. Texto Contexto Enferm. 2008 Out-Dez; 17(4):750-7.

6. Freire P. Pedagogia da autonomia: saberes necessários à prática educativa. $43^{\mathrm{a}}$ ed. São Paulo (SP): Paz e Terra; 2011.

7. Santin JR, Bettinelli LA, organizadores. Bioética e envelhecimento humano: inquietudes e reflexões. Passo Fundo (RS): UPF Editora; 2010.

8. Visentin A, Labronici L, Lenardt MH. Autonomia do paciente idoso com câncer: o direito de saber o diagnóstico. Acta Paul Enferm. 2007 Out-Dez; 20(4):509-13.

9. Oliveira LPBA, Menezes RMP. Representações de fragilidade para idosos no contexto da estratégia saúde da família. Texto Contexto Enferm. 2011 AbrJun; 20(2):301-9.

10. Gonçalves LHT, Scheir J. Grupo aqui e agora: uma tecnologia leve de ação sócio-educativa de enfermagem. Texto Contexto Enferm. 2005 Abr-Jun; 14(2):271-9.

11. Silva IJ, Oliveira MFV, Silva SED, Polaro SHI, Radünz V, Santos EKA, et al. Cuidado, autocuidado e cuidado de si: uma compreensão paradigmática para o cuidado de enfermagem. Rev Esc Enferm USP. 2009 Set; 43(3):697-703.

12. Freitas EV, Miranda RD. Parâmetros clínicos do envelhecimento e avaliação geriátrica ampla. In: Freitas EV, Py L, Cançado FAX, Doll J, Gorzoni ML. Tratado de geriatria e gerontologia. $3^{\mathrm{a}}$ ed. Rio de Janeiro (RJ): Guanabara Koogan; 2011.

13. Fontanella BJB, Ricas J, Turato ER. Amostragem por saturação em pesquisas qualitativas em saúde: contribuições teóricas. Cad Saúde Pública. 2008 Jan; 24(1):17-7.

14. Minayo MCS. O desafio do conhecimento: pesquisa qualitativa em saúde. $12^{\mathrm{a}}$ ed. São Paulo (SP): Hucitec; 2010.

15. Ministério da Saúde (BR), Conselho Nacional de Saúde. Resolução 196, de 10 de outubro de 1996: diretrizes e normas regulamentadoras de pesquisa envolvendo seres humanos. Brasília (DF): MS; 1996.

16. Rodrigues JSM, Ferreira NMLA. Caracterização do perfil epidemiológico do câncer em uma cidade do interior paulista: conhecer para intervir. Rev Bras Cancerol. 2010 Out-Dez; 56(4):431-41.

17. Nakatani AYK, Silva LB, Bachion MM, Nunes DP. Capacidade funcional em idosos na comunidade e propostas de intervenções pela equipe de saúde. Rev Eletr Enf [Internet]. 2009 [acesso 23 Jun 2012]; 11(1):144-50. Disponivel em: http:/ / www.fen.ufg. br/revista/v11/n1/v11n1a18.htm

18. Foucault M. História da sexualidade III: o cuidado de si. São Paulo (SP): Graal; 2009.

19. Pedreira LC, Oliveira MAS. Cuidadores de idosos dependentes no domicílio: mudanças nas relações familiares. Rev Bras Enferm. 2012Set-Out; 65(5):730-6.

20. Araújo C, Scalon C. Gênero e a distância entre a intenção e o gesto. Rev Bras Cienc Soc. 2006 Out; 21(62):45-68. 
21. Gomes R, Nascimento EF, Araújo FC. Por que os homens buscam menos os serviços de saúde do que as mulheres? As explicações de homens com baixa escolaridade e homens com ensino superior. Cad Saúde Pública. 2007 Mar; 23(3):565-74.

22. Rondini CA, Justo JS, Teixeira Filho FS, Lucca JAC, Oliveira PA. Análise das relações entre qualidade de vida e sobrecarga de cuidadoras de idosos de Assis, SP. Estud Pesq Psicol. 2011; 11(3):796-820.

23. Hoffmann FS, Müller MC, Rubin R. A mulher com câncer de mama: apoio social e espiritualidade. Mudanças Psicol Saúde. 2006 Jul-Dez; 14(2):143-50.

24. Brilhante AC, Lima MDC, Marreiro CM, Sousa BA, Aguiar MFM, Fonseca RC. Prostatectomia radical por via perineal (PRVP) em hospital não universitário: estudo de 13 casos. Rev Para Med. 2007 Dez; 21(4):43-6.

25. Lorencetti A, Simonetti JP. As estratégias de enfrentamento de pacientes durante o tratamento de radioterapia. Rev Latino Am Enfermagem. 2005
Nov-Dez; 13(6):944-50.

26. Jardim VCFS, Medeiros BF, Brito AM. Um olhar sobre o processo do envelhecimento: a percepção de idosos sobre a velhice. Rev Bras Geriatr Gerontol. 2006 Mai-Ago; 9(2):25-34.

27. Araújo LP, Helmer DS, Gomes L, Fukuda CC, Freitas MH. Medo à morte e ao morrer em idosas institucionalizadas e não institucionalizadas. Acta Sci Human Soc Sciences. 2009; 31(2):213-8.

28. Minayo MCS, Coimbra JR CEA. Antropologia, saúde e envelhecimento. Rio de Janeiro (RJ): Editora Fiocruz; 2002.

29. Xavier BB, Gentilli RML. Afetos e cooperação familiar como coadjuvantes do tratamento de câncer de mama em mulheres. Serv Soc Rev. 2012 Jan-Jun; 14(2):73-95.

30. Ferreira NML, Dupas G, Costa DB, Sanchez KOL. Câncer e família: compreendendo os significados simbólicos. Cienc Cuid Saude. 2010 Abr-Jun; 9(2):269-77. 